\title{
U.S. Federal GS Civil Service Pay Systems and Its Enlightenment to P.R.C.
}

\author{
Li Yongkang ${ }^{1,2}$, Sun Weiyan², Bai Yang ${ }^{1}$, Wang Xiaofen ${ }^{2}$ \\ ${ }^{1}$ School of Public Administration and Policy, Renmin University of China, Beijing, \\ P.R.China, 100872 \\ ${ }^{2}$ School of Public Management, Yunnan University of Economics and Finance, Kunming, \\ P.R.China, 650221 \\ (121651831@qq.com,1506784600@qq.com, byking1985@163.com,437535177@qq.com )
}

\begin{abstract}
As an extremely important part of civil service, the pay systems of civil servants provide basic life guarantee for civil servants. The method of literature and comparative analysis are adopted in this paper. Some viewpoints are put forward on U.S. federal General Schedule (GS) civil services pay systems. Firstly, they here have a wide scope, and include salary, allowances, bonuses, benefits, insurance; Secondly, their six characteristics are analyzed, including complete legal systems, rational position classification system, pay for performance, equity, flexible pay system, market-oriented; Thirdly, they supply six enlightenments to the pay systems reform of Chinese civil services below department or bureau level and non-leadership, including the acceleration of the pay systems legal construction, the improvement of the civil service position classification management system, the optimization of the civil services pay systems, the reform of the assessment methods of civil service, the introduction of flexible pay system, the establishment of market-oriented pay model. At last, it is concluded that a new road can be created to improve Chinese civil service pay system through absorbing the advanced experiments of other country according to Chinese actual situation.
\end{abstract}

Keywords: U.S. Federal General Schedule(GS) Civil Services, Pay Systems, Legal System, Market-oriented, Flexible

\section{Introduction}

Pay systems are various forms of financial returns, tangible service and benefits which are obtained by the staff as a party to the employment relationship. They include wages, benefits, insurance and so on. As for civil servants who provide public services, their pay system is far-reaching.

There are many researches on the US federal civil services on broad. American scholars pay more attention to the pay model. Such as, Profit sharing model (Jones and Svejnar, 1985); The U.S. federal government pays for performance (Kellough and Selden, 1997). 4p pay model, strategic pay model (Joseph J martocci Austria, 2002).The design, implementation, and maintenance of compensation systems are important parts of strategic human resources management(SHRM)(Joan E. Pynes, 2004:226-261). Designing and creating an effective compensation plan : devote to a step-by-step discussion of constructing and maintaining an effective salary structure, bringing together objectives, structural alternatives, and pay administration policies(Gilbert B. Siegel, 2010). Meanwhile, the U.S. federal government applies the methods and technology of human resource management to make a pay decision.

Chinese scholars attach great importance to introduce the U.S. federal government civil service pay systems. For example, the introduction of broadbanding (Wang Jianchang,2004); describing the U.S. civil service wage benefits and civil service pay basis :job classification system(Li Yuanbao, 2007); the reform of U.S. federal government civil service pay systems(Wu Zhihua, 2006). introducing U.S civil service pay systems and its enlightenments to China : strengthening of the legal construction, improving performance appraisal methods of civil service(Liu Biqiang, 2010).

Chinese civil servants' pay system is not perfect in the modern time. It needs to absorb 
the advantages from the pay system of other countries. The United States has a relatively sound pay system. Through the introduction of the U.S. federal government civil service pay systems, some references will be provided for Chinese civil servants pay systems reform, especially the pay system reform of Chinese civil service below department or bureau level and non-leadership.

\section{The Contents of U.S. Federal GS Civil Service Payment Systems}

What is the Contents of U.S. Federal Civil Service Pay Systems? The term "total compensation" is used to describe not only salary and wages, but also all the plans, programs, benefits and opportunities that become available to you through your employment. The University of Guelph offers a competitive total compensation program involving payroll, group benefits, pension administration as well as various assistance programs and subsidies for employees of the University. The Total Compensation package helps attract, retain and motivate a talented and diverse workforce (Total Compensation Package,2012). We think here that the pay systems have the same scope with Total Compensation package. Therefore, the Contents of U.S. Federal Civil Service Pay Systems include salary, allowances, bonuses, benefits, insurance.

\subsection{Salary}

Salary is a major component of the remuneration. The compensation of U.S. federal civil service has evolved into a complex set of pay systems including two categories of seven series. The first category is the statutory pay system, suitable for white-collar employees, including General Schedule (GS), diplomatic personnel payroll, veterans health administrators. The second one is other pay systems, including Executive Schedule(ES) ,Senior Executive Service (SES), the Federal Wage System(FWS) for blue-collar employees. The FWS is a uniform pay-setting system that covers Federal appropriated fund and nonappropriationed fund blue-collar employees who are paid by the hour. The system's goal is to make sure that Federal trade, craft, and laboring employees within a local wage area who perform the same duties receive the same rate of pay. The FWS includes 132 appropriated fund and 125 nonappropriated fund local wage areas. Successful labor-management partnership is the hallmark of the FWS, with labor organizations involved in all phases of administering the pay system.( Office of Personnel Management ,2012) However, 71\% of federal civilian employees are paid under the GS, the remaining 29\% are paid under other systems . Because the majority of the federal civil service is paid under GS, this paper mainly introduces this part.

\begin{tabular}{|r|r|r|r|r|r|r|r|r|r|r|r|}
\hline & & & & & & & & $\begin{array}{l}\text { WITHIN } \\
\text { GRADE }\end{array}$ & & & \\
Grade & Step 1 & Step 2 & Step 3 & Step 4 & Step 5 & Step 6 & Step 7 & Step 8 & Step 9 & Step 10 & AMOUNTS \\
\hline 1 & $\$ 17,803$ & $\$ 18,398$ & $\$ 18,990$ & $\$ 19,579$ & $\$ 20,171$ & $\$ 20,519$ & $\$ 21,104$ & $\$ 21,694$ & $\$ 21,717$ & $\$ 22,269$ & VARIES \\
\hline 2 & 20,017 & 20,493 & 21,155 & 21,717 & 21,961 & 22,607 & 23,253 & 23,899 & 24,545 & 25,191 & VARIES \\
\hline 3 & 21,840 & 22,568 & 23,296 & 24,024 & 24,752 & 25,480 & 26,208 & 26,936 & 27,664 & 28,392 & 728 \\
\hline 4 & 24,518 & 25,335 & 26,152 & 26,969 & 27,786 & 28,603 & 29,420 & 30,237 & 31,054 & 31,871 & 817 \\
\hline 5 & 27,431 & 28,345 & 29,259 & 30,173 & 31,087 & 32,001 & 32,915 & 33,829 & 34,743 & 35,657 & 914 \\
\hline 6 & 30,577 & 31,596 & 32,615 & 33,634 & 34,653 & 35,672 & 36,691 & 37,710 & 38,729 & 39,748 & 1019 \\
\hline 7 & 33,979 & 35,112 & 36,245 & 37,378 & 38,511 & 39,644 & 40,777 & 41,910 & 43,043 & 44,176 & 1133 \\
\hline 8 & 37,631 & 38,885 & 40,139 & 41,393 & 42,647 & 43,901 & 45,155 & 46,409 & 47,663 & 48,917 & 1254 \\
\hline 9 & 41,563 & 42,948 & 44,333 & 45,718 & 47,103 & 48,488 & 49,873 & 51,258 & 52,643 & 54,028 & 1385 \\
\hline 10 & 45,771 & 47,297 & 48,823 & 50,349 & 51,875 & 53,401 & 54,927 & 56,453 & 57,979 & 59,505 & 1526 \\
\hline 11 & 50,287 & 51,963 & 53,639 & 55,315 & 56,991 & 58,667 & 60,343 & 62,019 & 63,695 & 65,371 & 1676 \\
\hline 12 & 60,274 & 62,283 & 64,292 & 66,301 & 68,310 & 70,319 & 72,328 & 74,337 & 76,346 & 78,355 & 2009 \\
\hline 13 & 71,674 & 74,063 & 76,452 & 78,841 & 81,230 & 83,619 & 86,008 & 88,397 & 90,786 & 93,175 & 2389 \\
\hline 14 & 84,697 & 87,520 & 90,343 & 93,166 & 95,989 & 98,812 & 101,635 & 104,458 & 107,281 & 110,104 & 2823 \\
\hline 15 & 99,628 & 102,949 & 106,270 & 109,591 & 112,912 & 116,233 & 119,554 & 122,875 & 126,196 & 129,517 & 3321 \\
\hline
\end{tabular}

(Data sources: Office of Personnel Management , 2012. http://www.opm.gov/oca)

Table 1: Salary Table 2012-GS:General Schedule Pay Scale, Annual Rates by Grade and Step

In table $1, \mathrm{GS}$ is separated into 15 grades (GS-1,GS-2,etc.up to GS-15); each grade is separated into 10 steps. GS position sequences are divided into single-interval sequence (such as GS-2 - GS-8) and double-interval sequence (such as GS-5, 7,9,11).
In table 2 , GS Salary Table of U.S. Federal civil service is a basic standard, the locality pay will be adjusted according to the conditions of each region on this basis. Such as, Alaska payroll is more 24.69percent than the annual wage of Federal civil service: $17803+17803 \times 24.69 \%=22199($ see table 3$)$. 


\begin{tabular}{|l|c|}
\hline Locality & Annual rates \\
\hline State of Alaska & $24.69 \%$ \\
\hline State Of Hawaii & $16.51 \%$ \\
\hline Richmond, Va & $16.47 \%$ \\
\hline Raleigh-Durham-Cary, Nc & $17.64 \%$ \\
\hline Seattle-Tacoma-Olympia, Wa & $21.81 \%$ \\
\hline
\end{tabular}

(Data Source :http://www.opm.gov/oca)

Table 2: GS annual pay rate in some states

\begin{tabular}{|c|c|c|c|c|c|c|c|c|c|c|}
\hline Grade & Step 1 & Step 2 & Step 3 & Step 4 & Step 5 & Step 6 & Step 7 & Step 8 & Step 9 & Step 10 \\
\hline 1 & $\$ 22,199$ & $\$ 22,940$ & $\$ 23,679$ & $\$ 24,413$ & $\$ 25,151$ & $\$ 25,585$ & $\$ 26,315$ & $\$ 27,050$ & $\$ 27,079$ & $\$ 27,767$ \\
\hline 2 & 24,959 & 25,553 & 26,378 & 27,079 & 27,383 & 28,189 & 28,994 & 29,800 & 30,605 & 31,411 \\
\hline 3 & 27,232 & 28,140 & 29,048 & 29,956 & 30,863 & 31,771 & 32,679 & 33,586 & 34,494 & 35,402 \\
\hline 4 & 30,571 & 31,590 & 32,609 & 33,628 & 34,646 & 35,665 & 36,684 & 37,703 & 38,721 & 39,740 \\
\hline 5 & 34,204 & 35,343 & 36,483 & 37,623 & 38,762 & 39,902 & 41,042 & 42,181 & 43,321 & 44,461 \\
\hline 6 & 38,126 & 39,397 & 40,668 & 41,938 & 43,209 & 44,479 & 45,750 & 47,021 & 48,291 & 49,562 \\
\hline 7 & 42,368 & 43,781 & 45,194 & 46,607 & 48,019 & 49,432 & 50,845 & 52,258 & 53,670 & 55,083 \\
\hline 8 & 46,922 & 48,486 & 50,049 & 51,613 & 53,177 & 54,740 & 56,304 & 57,867 & 59,431 & 60,995 \\
\hline 9 & 51,825 & 53,552 & 55,279 & 57,006 & 58,733 & 60,460 & 62,187 & 63,914 & 65,641 & 67,368 \\
\hline 10 & 57,072 & 58,975 & 60,877 & 62,780 & 64,683 & 66,586 & 68,488 & 70,391 & 72,294 & 74,197 \\
\hline 11 & 62,703 & 64,793 & 66,882 & 68,972 & 71,062 & 73,152 & 75,242 & 77,331 & 79,421 & 81,511 \\
\hline 12 & 75,156 & 77,661 & 80,166 & 82,671 & 85,176 & 87,681 & 90,186 & 92,691 & 95,196 & 97,701 \\
\hline 13 & 89,370 & 92,349 & 95,328 & 98,307 & 101,286 & 104,265 & 107,243 & 110,222 & 113,201 & 116,180 \\
\hline 14 & 105,609 & 109,129 & 112,649 & 116,169 & 119,689 & 123,209 & 126,729 & 130,249 & 133,769 & 137,289 \\
\hline 15 & 124,226 & 128,367 & 132,508 & 136,649 & 140,790 & 144,931 & 149,072 & 153,213 & $155,500^{*}$ & $155,500^{*}$ \\
\hline
\end{tabular}

(Data sources: Office of Personnel Management ,2012.http://www.opm.gov/oca)

Table 3 salary table 2012-ak incorporating a locality payment of $24.69 \%$ state of Alaska effective January 2012 Annual Rates by Grade and Step

\subsection{Allowance}

The allowance are various supplements which are paid according to the specific work of civil service wages, Its main function is used to adjust contradiction in the allocation of income. The subsidies of federal civil service in GS mainly include two categories: area adjustment allowance and non-taxable allowance. Non-taxable allowance includes living allowances, post allowances and housing allowances. Area adjustment allowance is applicable for American territories and overseas areas, a large coverage, and generally accounts for a certain proportion of the salaries of public servants, $4.76 \%$ in 2010. Every allowance with their respective scope of application is the root of the specific environment, such as post allowance, which is given to the civil service in the diplomatic area, but the difference between positions can not exceed $25 \%$ of the basic wage rate. In addition, the U.S. civil service also receives overtime allowance and uniform allowance when GS civil service work more than eight hours which is considered overtime. Overtime allowance can be divided into night overtime, Sunday overtime and holiday overtime. Each allowance has a different allowance standards; uniform allowance can not be more than 125 dollars.

\subsection{Bonus}

Bonus is the form of excess labor remuneration, which is characterized by unity, flexibility, timeliness, and honor. The bonus of U.S. federal civil service in GS mainly include work achievement award and a cash prize of plan. Achievement award's amount should not be more than $10 \%$ of basic salary and not be less than $2 \%$ of basic salary. However, the achievement award can be given more than $10 \%$ of basic salary and not exceed $20 \%$ by approval of the heads of departments. The amount of a cash prize is not more than 10 thousand dollars, but by the approval of the Personnel Management Department, civil service may be granted more than $\$ 10,000$ but not exceed $\$ 25,000$. Meanwhile, In order to attract, retain and inspire with excellent public management talent, the U.S. Government introduces the 3RS measures: "Recruitment Bonuses", "Relocation Bonuses", "Retention Allowances"(Wu Zhihua, 2006). In addition, there are still many types of bonus for GS civil services, such as Performance Award, Service Award and Gain sharing .

\subsection{Welfare}


Welfares are also known as the marginal salary, including the remuneration of all non-working hours, employees' services and protection schemes. Welfares contain required welfares and discretionary welfares (Martocci Austria ,2002). The welfares of civil services are A series of measures taken by the public sector to improve and enhance living standards of the civil service. The welfare of civil service(GS) in the United States, include annual leave, family and medical leave, sick leave, and so on. It is noteworthy that the leave of U.S. civil services mainly includes annual leave and paid vacation. The annual leave is calculated according to length of service. If the length of service is less than three years, annual leave is three weeks. Generally ,the annual leave of most civil services is no more than 30 days. United States civil service can enjoy paid vacation for 13-26 days in addition to the enjoyment of the statutory holidays each year(Zouxian Qi, Wan Fu-yao Hu Shubin, 2004). Vacation of federal civil services (GS) can be transferred, and can be transacted between civil services and department of personnel, which makes the vacation more flexible and market-oriented.

\section{5 .Insurance}

Insurance can compensate for the loss of risk, and reduce the extent of losses. Insurance of civil servants mainly refers to the social insurance. Insurances of GS civil services in general include health insurance, life insurance, the Federal Flexible Spending Account Program (FSAFEDS) and pensions. Health insurances mainly include hospitalization and medical expenses insurance; prescription drug coverage; dental, vision coverage, long term unemployment insurance and accident insurance. Life insurances include term life insurance, universal life and whole life insurance. Pension is an important form of employee retirement plans in the United States. The pensions of civil servants in general are Civil Service Retirement System (CSRS) and Federal Employees' Retirement System (FERS) (Zhao Long, Shen Anqi,2009). FERS is the current main pension system, and U.S. is in the stage being transformed from civil service retirement system to federal employee retirement system. Under Civil Service Retirement System, pensions are fully linked with the inflation rate, and its account funds by the Federal Ministry of Finance to ensure and increase the value of the pension. In contrast, the federal employee retirement system is more extensive, flexible and portable.

\section{Characteristics of U.S. Federal GS Civil Service Pay Systems}

Six Characteristics of U.S. federal GS Civil Service Pay Systems will be analyzed in this part. They are complete legal systems, rational position classification system, pay for performance, equity, flexible pay system, market-oriented.

\subsection{Complete legal systems}

There is a relatively complete legal systems for U.S. Federal Civil Service Pay Systems, all aspects of which are formulated by laws. The federal government 's first pay law was enacted in 1938, named "Fair Labor Standards Act (the FLSA)", which provides minimum wage and overtime pay and becomes the base of the U.S. pay laws. In 1963, the FLSA was amended by the Equal Pay Act, Which prohibits unequal pay differences for men and women who are performing equal work in jobs requiring equal skill, effort, and responsibility and performed in the same under similar working conditions( Joan E. Pynes, 2004: 256). Both Working Hours and Safety Standards Act of 1962 and McNamara - O'Hara Service Contract Act of 1965 make detailed provisions for continue revenue, safety and working hours. American Disability Act of 1930 and Family Leave and Sick Leave Act of 1993 guarantee the rights of the disabled and provide needs for families.

In Donald and John's opinion, there are four basic federal laws that is the base of pay systems in the government laws and regulations. They are: Fair Labor Standards Act of 1938;Equal Pay Act of 1963;1964 Civil Rights Act, Title VII; Age Discrimination in Employment Act of 1967(Donald E Klingner and John Nalbandian, 2001:179).

What's more, there are specific laws only for the federal civil service, such as Pendleton Act of 1883 , which marks to establish U.S. civil service system and provides the basic pay system for civil service; Civil Service Reform Act of 1978 ,which reforms the pay system and confirms the merit system principles; Federal Civil Service Comparable Wages Act of 1990, which formulates the level of civil service pay system that should be consistent 
with corporate wage. In addition, the Federal Wage Reform Act of 1962 and the Federal Wage Equilibrium Method of 1970,make provisions about federal civil service wages, insurance, welfare.

\subsection{Rational position classification system}

The U.S. civil service pay system is based on a civil service position classification system. The United States is a typical position classification country, which has a strict, scientific and elaborate position classification system. According to the Classification Act of 1949, civil servant positions are divided into 2 parts. The first part is the general schedule(GS) which includes15-grade (from GS-1 to GS-15), each level is divided into 10 ranks. Among them, GS-1 - GS-7 provide for elementary positions, GS- 8 - GS- 12 provide a relatively high level positions, GS-13 - GS-15 require positions that like first-line senior technical experts, first-class posts(Sun Boying and Qi Guanghua, 2005:17). The second part is the GPS that includes GS-16, GS-17,GS 18.GPS was abolished in 1954. In accordance with the 1978 Civil Service Reform Act, the federal government builds a relatively independent senior civil servant schedule, including 16, 17, 18 of the original GS grades. According to current standards, all of the positions are divided into two major categories: white-collar and blue-collar. The majority of blue-collar staffs are paid for the Federal Wage System (FWS), while GS-salary are applicable to the GS federal civil servants, which are the different divisions of the 23 occupational categories, accordance with the responsibilities and qualifications. Each type of occupations contains less 100 occupational title series, each occupational series corresponds to a grade in the GS system(Liu Yi, 2005:66).

\subsection{Pay for performance}

The merit system is performed in U.S. federal civil service pay system. Since 1883 U.S. Congress passed the Civil Service Law, the merit system has been adopted . Equal pay for equal work and pay for performance are two important parts of the merit system. Performance evaluations are an important component of evaluating the knowledge, skills, abilities, and other characteristics(KSAOCs), the result can help to develop compensation and reward systems(Joan E. Pynes,2004:198)."Performance, achievement and merit are synonymous in compensation systems based on outputs or outcomes. Reward in these systems is for specified objectives achieved in quantitative or qualitative terms. " Individual performance and group performance systems are two types systems for share the reward-for-achievement attribute(Gilbert B. Siegel, 2010:668). In 1994, the federal government made the "Government Performance and Results Act performance plan"to evaluate and strengthen government performance management. In the following years, the federal government made a lot of laws about the merit system. On performance, we can also see from the wage schedule, each grade is divided into different steps, all civil services have their own "career ladder" . The incentive pay will be provided for civil services in accordance with their performance to ensure the enthusiasm of the civil service and the success of the incentive pay.

\subsection{Equity}

According to equity theory, employees compare their job inputs and outputs to the inputs and outputs of others performing similar tasks. If they perceive that their ratio of inputs to outputs is on a par with those of the others to whom they compare themselves, a state of equity is said to exist. If the ratios are unequal, inequity exists, and employees who feel that they are outperforming their colleagues will believe that they are underrewarded. In order to keep equity, the U.S. federal government establishes three types of equity: external, internal, and employee(Joan E. Pynes, 2004:227).

External equity is the standard that compares an employer' wages with the rates prevailing in external markets for the employee' s position(Joan E. Pynes,2004:227). The U.S. federal government builds a wage survey system to ensure that the salaries of civil service are broadly consistent with the private sector wages .The United States Civil Service Reform Act regulates that "the Office of Personnel Management, the Chief of Management and Budget and the Department of Labor investigate private sector wage levels across the country every year. And the findings will be compared with the same level salaries of civil service. Besides, the proposal should be taken to adjust the salaries of civil services to the Congress and the President. Approved by Parliament, the President issues Executive 
Order to implement and try to ensure that the wages of civil service in the middle and low grades are at the same level with the private sector employees' wages"

Internal equity is the standard that requires employers to set wages for jobs in their organizations that correspond to the relative internal value of each job. To institute internal equity in its compensation structure, a variety of factor comparison systems are used to determine job value, such as, experience, education, complexity of duties, supervision received, supervision exercised, mental demands, physical demands and working conditions. In 1949, Congress passed the Classification Act of 1949,which established the GS systems that defines the basic compensation system used by nonmanagerial white-collar positions. Because the GS has been criticized for its lack of flexibility in supporting individual agency missions, structures and cultures and for its inability to respond to rapidly changing external conditions, the National Performance Review(1993) has recommended modifying the GS by reducing the number of occupational categories and permitting agencies to establish broadbanding systems(Joan E. Pynes, 2004:230-234).

Employee equity is the comparison of pay across employees performing the same or similar work. Most compensation structures include pay ranges. A pay range exists when one or more rates are paid to employees in the same job, and reflects the minimum and maximum that the employer will pay for the position. Table 1 presents the GS Pay Sale for federal civil service. Each grade has ten pay-level increments.

To determine pay ranges, the government needs to establish what the current market rates are for benchmark jobs. After the data have been compiled, organizations develop salary ranges to fit their structure. Each salary range should have a midpoint, a minimum, maximum(Joan E. Pynes,2004:234-235).

Three aspects above achieve a fair and transparent pay system.

\subsection{Flexible pay system}

The U.S federal government makes the maximum salary standard of civil services which is the special pay rules allowing the administrative agency to give civil services more than regular salaries. It is a compensation standard that is designed for reemployment, transfer, rearranged new job, promotion and other position change of civil services, and personnel institutions perform higher than conventional compensation according to their own actual conditions. Broadbanding was introduced by the federal government out of frustration with the inflexible federal classification and pay system and to increase flexibility, managerial control, and accountability(Risher and Schay ,1994). The use of broadbanding eliminates having to maintain many narrow salary grades. Boardbanding grants managers the discretion to offer a variety of starting salaries and to reward employees with pay increases or different job assignments as needed to fulfill the agency's mission. Advocates of broadbanding claim that it simplifies pay administration ,facilitates career developments, and links compensation with Strategic Human Resource

Management(SHRM)(Joan.E.Pynes,2004:241242). Although Boardbanding exists some problems, it has an effect on encouraging civil services' initiatives in working. What is more, it improves the efficiency of public services.

\subsection{Market-oriented}

The pay system of the U.S. civil services is market-oriented, adjust pay system based on the market situation. First of all, on the basis of the salary survey and accordance with the current situation of national economic and social development, economic development, fiscal budget, the price index, the inflation index factors, the wage levels varies to adjustment. Secondly, introducing the measures of market to improve the pay system, such as buying or selling the leave. Finally, taking advantage of market mechanisms to improve the civil service insurance system, measures are taken to achieve the market-oriented operation of the insurance system, such as the unified management of civil services' pension account funds by federal agencies, some investment in federal securities.

\section{Enlightenment for P.R. China}

Civil Service Law of the People's Republic of China was passed by National People's Congress in 2005, in which Chinese civil servants' wages include basic salary, allowances, subsidies and bonuses. Public 
servants' salary includes the position salary and grade wage. Wages are 27 grades, 14 Steps, all grades and positions exist corresponding relationship .The grades of non-leadership job is on or below department or bureau level, and the wages of department or bureau level correspond to grade 8-grade13;deputy department or bureau level corresponds to grade10- grade15; county level corresponds to grade 12- grade18, deputy county level corresponds to grade14-grade 20; the township at the section level corresponds to $t$ grade 16grade 22; the deputy township branch level corresponds to 17-24 grade. Therefore, Chinese civil services below department or bureau level $(92 \%)$ are similar with the U.S. federal GS $(71 \%)$ civil services, and the advantages of pay systems of GS can supply reference for Chinese civil services below department or bureau level and non-leadership.

\subsection{The acceleration of the pay systems legal construction}

The legal construction of China's pay system is far from perfect. There is no special law in respect of emoluments. The current laws are only the Civil Service Law and related regulations, such as the civil service wage reform program, the Civil service reward (Trial) . Compared with the United States, the legalization process of the pay in China is lagging behind. It is necessary to accelerate of the pay systems legal construction. Firstly, special laws of pay should be developed to rule the behavior of management, provide a strong basis to solve the question of pay and protect public servants' rights to gain the allowances, benefits, insurance, etc. Secondly, the law procedures on the civil service pay standard and the specific implement department should be improved for the lack of procedural norms of the civil service pay system. Finally, civil service pensions implement act should be made to implement the details of the allowances and subsidies. The development of these laws or regulations can guarantee the realization of the rights of civil service pay.

\subsection{The improvement of the civil service position classification management system}

Positon classification is the main body of the U.S. civil service, supplemented by grade classification, and sets up different positions and ranks. China's Civil Service Act provides that "the state carries out civil service position classification system." China's civil service positon categories are divided into the class of integrated management, the class of professional and technical, and the class of administrative law inplement. Civil service jobs are divided into leadership and non-leadership. The majority of civil services in China are non-leadership, but they take over most of the work. Thus the unfair of pay may lead to inefficient management. Therefore the US federal GS Civil Service classification system can be studied by Chinese government. For example, the different jobs of the non-leadership in the civil service can be divided into more grades, occupational group, each position may corresponds to at least 6 to 8 grades.

\subsection{The optimization of the civil services' pay systems}

The U.S. federal GS civil service salary system is built on the basis of scientific position classification, and the structure is relatively more scientific and reasonable. GS salary is main body, supplemented by allowance and welfare, and allowances are generally not more than $10 \%$ of the total amount of salaries. While In China, civil service's wage level is generally lower, and the proportion is smaller. But the ratio of benefits and allowances are larger, the salary structure is imbalance. To optimize the structure: Firstly, improving the level of wages of civil servants, so that the salary can play a fundamental role. Secondly, confirming the proportion of civil servants' wages, allowances and benefits to increase the incentive of the pay. Thirdly, because the phenomenon that allowances and benefits is due to different local places and sectors is more serious, all types of allowances and benefits should be limited strictly to ensure they are fair and reasonable.

\subsection{The reform of the assessment methods of civil service}

As the civil service assessment has a direct impact on the salaries of civil servants, more diverse, scientific assessment methods should be established. Civil Servant Law of 2005 provides that the civil service assessment should be in accordance with administrative privileges, a whole assessment of the civil service includes virtue, ability, diligence, performance, probity. Thus, the assessment methods of non-leadership civil servants are difficult to find specific indicators to quantify and lack of appropriate quantitative methods. 
The accuracy of results is not high and lack of scientific. Therefore, some advanced technology methods of the US, such as balanced scorecard etc, should be introduced.

\subsection{The introduction of flexible pay system}

The grades of China's non-leadership jobs are too less and lack of flexibility, the incentive is not obvious. Thus, first of all, a dynamic adjustment mechanism should be introduced in order that the wages of civil servants can be external competitive and internal attractive. Secondly, a flexible wage structure should be established in order that the wage structure has both the fixed part and the floating section, and enhances the incentive role of the wage. Thirdly, broaden the corresponding grades of the positions and set a more reasonable wage fluctuation, in that the wage incentive effect is more pronounced. Finally, establish a flexible pay and broad banding, and the right of adjusting pay policy should be given to local governments to some extent, so that the system can be more practical and efficient.

\subsection{The establishment of market-oriented pay model}

The wage survey system should be improved to establish a set of dynamic and reasonable wage level. At the same time, the pay standard should be reference to the private sector's wage to make the amount of wages of civil servants more fair and competitive. If the conditions are ripe for local governments, they can timely explore benefits of market mechanisms of the civil service and smooth welfare trading platform. The management department of the civil service pay should improve the civil service insurance system and create an open, fair, competitive and orderly market mechanism to civil service laws or regulations. Furthermore, adhere to combine social insurance with commercial insurance, voluntary insurance with compulsory insurance, and make full use of market instruments to improve civil service medical, unemployment, maternity, industrial injury insurance. Pay more attention to the pension, take a cautious measure to the investment securities, to guarantee the pension increase.

\section{5 .Conclusion}

There are a lot of characteristics on the pay systems of the U.S. GS civil service, such as complete legal systems, rational position classification system, pay for performance, equity and so on. All of them can supply reference for the improvement of pay systems of Chinese non-leadership civil servants. Relevant laws and regulations should be established; The flexible pay and broad banding should be introduced; Market-oriented instruments should be made full use of and the non-leadership jobs classification should be improved. What is more, we should learn more from the pay systems of the federal GS civil services. However, learning does not mean blindly copy, we should absorb the advantages of other country according to Chinese actual situation. Then we can create a new road to improve Chinese civil service pay systems.

\section{References}

[1]Risher,H., Schay, B.W. Grade Banding: The Model for Future Salary Programs[J]. Public Personnel Management,1994,32(3):187-199.

[2]George T. Mirkovic, Jerry M. Newman. Compensation Management[M]. Renmin University Press, 2008:6.(in Chinese)

[3]Joseph J. Martocci Austria. Strategic Compensation : Human Resource Management Practices[M]. Social Sciences Academic Press, 2002:8 -9.

[4]Donald E Klingner, John Nalbandian. Public Personnel Management: Contexts and Strategies[M]. Renmin University Press,2001:179.(in Chinese)

[5]Joan E.Pynes.Human Resources Management for Public and Nonprofit Organizations[M]. Jossey-Bass A Wiley Imprint, 2004:227-261.

[6]Gilbert B. Siegel.Designing and Creating an Effective Compensation Plan(Chapter 27). Stephen E. Condrey and James L. Perry. Handbook of Hunan Resource Management in Government[M]. Jossey-Bass A Wiley Imprint.2010:663-685.

[7]Li Yuanbao. Public Human Resources Development and Management[M]. Economic Science Press ,2007:334 -351.(in Chinese)

[8]Liu Yi. Research and Enlightenment of the U.S. Federal Government Civil Servant Pay ystems[J]. Chinese Human Resource Development ,2005:66.(in Chinese) 
[9]Liu Bijiang. American Civil Service Pay Systems and Its Enlightenment[J]. South on the Journal,2010:51-53.(in Chinese)

[10]Kellough and Selden. Pay-for-performance Systems in State Government[J]. Review of Personnel Administration, 1997:5.

[11]Sun Boying and Qi Guanghua. Public Sector Human Resource Management[M]. Renmin University Press,2005:17.(in Chinese)

[12]Wang Jianchang. The Introduction of Broadbanding in Government Departments[J]. Administration of Chongqing,2004:2.(in Chinese)

[13]Wu Zhihua.U.S Civil Service Reform and Transformation[M].Shanghai Jiao Tong University Press ,2006:18.(in Chinese)

[14]Wu Zhihua.The Transformation of the U.S Civil Service and Its Implications[J]. Administration of China,2005:66.(in Chinese)

[15]Yang Weiguo\&Wen Yanrui .Foreign Public Sector Performance Pay Reform: Background, Model and Effect. National School of Administration of China ,2011:125.(in Chinese)

[16]Zou Xianqi, Wan Fuyao, Hu Shubin. American Wages and Benefits System Inspection Report[J]. Contemporary Economic ,2004:21.(in Chinese)

[17]Zhao Long, Shen Anqi.China-US Civil Service Wages and Benefits Comparative[J]. Institute of Public Administration of Chengdu, 2009:13-15.(in Chinese)

[18]Office of Personnel Management ,2012.http://www.opm.gov/oc a/12tables/indexGS.asp.

[19]Federal-wage-system.Wikipedia.http://en. wikipedia.org/wiki/Federal_Wage_System. [20]Senior Executive Service (US).Wikipedia. http://www.opm.gov/oca/wage/fwsfact.asp. ckage. 